\title{
Determinan Literasi Keuangan pada Pelaku Usaha Mikro, Kecil, dan Menengah (UMKM) di Kota Mataram
}

\author{
Taufiq Chaidir*, Ida Ayu Putri S, Gusti Ayu Arini dan Baiq Ismiwati \\ Jurusan Ilmu Ekonomi Studi Pembangunan \\ Fakultas Ekonomi dan Bisnis-Universitas Mataram \\ *Corresponding Author: taufiqch@unram.ac.id
}

\section{Info Artikel}

Kata Kunci:

Literasi Keuangan, UMKM, Pengetahuan, Sikap, dan Perilaku Keuangan

Keywords:

Financial Literacy, MSMEs, Knowledge, Attitudes, and Financial Behavior

\section{ABSTRAK}

Tujuan penelitian ini adalah untuk membuktikan bahwa tingkat pendidikan, usia, jenis kelamin, pendapatan, dan jarak domisili sebagai determinan yang mempengaruhi literasi keuangan serta untuk membuktikan bahwa pengetahuan, sikap, dan perilaku sebagai indikator yang mempengaruhi literasi keuangan pelaku UMKM di Kota Mataram.

Jenis penelitian yang digunakan adalah penelitian eksplanasi. Metode pengumpulan data adalah sampel survey. Teknik penentuan sampel menggunakan probability random sampling, berdasarkan kluster sampling, jumlah sampel ditentukan sebanyak 105 pelaku UMKM. Model analisis yang digunakan untuk estimasi dan pengujian hipotesis menggunakan model analisis jalur Partial Least Squares (PLS).

Hasil penelitian membuktikan bahwa pendidikan, umur, dan jarak domisili tidak berpengaruh terhadap Literasi Keuangan. Tidak terdapat perbedaan yang signifikan tingkat literasi antara perempuan dan laki-laki. Sedangkan pendapatan berpengaruh terhadap Literasi Keuangan pelaku UMKM di Kota Mataram. Dari tiga indikator hanya pengetahuan yang berpengaruh, sedangkan sikap dan perilaku tidak berpengaruh terhadap Literasi Keuangan. Nilai R-square (nilai original sampel) adalah sebesar 0,139 membuktikan bahwa hasil estimasi inner dan outer model adalah predictive relevan.

Rendahnya literasi keuangan pelaku UMKM menjadi tantangan terhadap penyedia layanan keuangan guna menghadirkan solusi yang tepat yakni sosialisai dan eduksi melalui perencanaan dan pengelolaan keuangan yang lebih baik, guna melindungi mereka dari usaha yang tidak sehat di pasar keuangan.

\section{ABSTRACT}

The purpose of this study is to prove that the level of education, age, sex, income, and distance of domicile as determinants that affect financial literacy and to prove that knowledge, attitudes, and behaviors are indicators that influence the financial literacy of MSMEs in Mataram City.

This research type is explanatory research. The data collection method is a survey sample. The technique of determining the sample uses probability random sampling, based on cluster sampling, the number of sample is determined as many as 105 MSMEs. The analysis model used for estimation and hypothesis testing uses the Partial Least Squares (PLS) path analysis model.

The result of the study prove that education, age, and distance of domicile do not affect Financial Literacy. There is no significant difference in the level of literacy between women and men. While income influences the Financial Literacy of 


\section{Elastisitas - Jurnal Ekonomi Pembangunan \\ Vol. 2 No. 1, Maret 2020}

MSMEs in Mataram City. From three indicators, only knowledge is influential, while attitudes and behaviors have no effect on Financial Literacy. R-square value (original sample value) of 0.139 proves that the estimation results of inner and outer models are predictive relevant. The low financial literacy of MSMEs is a challenge for financial service providers to present appropriate solutions, namely socialization and education through better financial planning and management, to protect them from unhealthy businesses in the financial markets.

\section{PENDAHULUAN}

Data Kementerian Koperasi dan UKM tahun 2017 menunjukkan bahwa Usaha Mikro, Kecil, dan Menengah (UMKM) di Indonesia mendominasi jumlah unit usaha yaitu sebanyak 62,9 juta atau 99,99 persen dan mampu berkontribusi sebesar 60,0 persen terhadap Produk Domestik Bruto (PDB). Di Provinsi Nusa Tenggara Barat (NTB) sendiri, pada periode yang sama berdasarkan data dari Dinas Koperasi dan UMKM Provinsi NTB, terdapat lebih dari 644 ribu unit UMKM dengan jumlah tenaga kerja yang terserap lebih dari 1,8 juta orang.

Gambaran faktual terkait dengan data UMKM baik menyangkut klasifikasi usaha maupun penyerapan tenaga kerja di Kota Mataram pada tahun 2017 adalah sebagai berikut. Klasifikasi usaha mikro sebanyak 46.321, usaha kecil 11.007, dan usaha menengah sebanyak 632, dengan demikian secara keseluruhan jumlah pelaku usaha UMKM sebanyak 57.960, serta menyerap tenaga kerja sebanyak 135.722 orang. (BPS, 2017)

Trend perkembangan pelaku usaha UMKM secara nasional sampai ke tingkat Kota Mataram cukup signifikan. Hal tersebut tidak hanya berkontribusi terhadap penyerapan tenaga kerja, namun di sisi lain bahwa UMKM secara berkelanjutan mampu meningkatkan kapasita poroduksi, menggerakkan perekonomian nasional dan atau perekonomian daerah, mendorong pertumbuhan ekonomi, yang pada akhirnya mampu mengentaskan kemiskinan, serta meningatkan kesejahteraan masyarakat secara umum, dan pelaku usaha UMKM secara khusus.

Kekuatan dan potensi dari UMKM adalah dikenal memiliki resistensi terhadap krisis, karena pada umumnya UMKM adalah berbasis pada bahan baku dan memiliki target pemasaran domestik. Di balik potensi tersebut, UMKM masih menghadapi sejumlah tantangan atau kendala, antara lain permodalan dan akses pembiayaan, lemahnya kapasitas sumber daya manusia, serta keterbatasan jangkauan pasar (BI, 2018). Sedangkan hasil riset Wordl Bank (2016) mengungkapkan bahwa terdapat empat permasalahan utama yang dihadapi UMKM secara umum yaitu aspek pembiayaan, aspek peluang usaha, kapasitas sumber daya manusia (SDM), dan kelembagaan UMKM, serta regulasi dan birokrasi.

UMKM berjuang untuk mempertahankan atau memperluas karena banyak kendala yang mereka hadapi, terutama kurangnya akses ke pinjaman bank, kesulitan dalam pemasaran, dan akses terbatas untuk teknologi maju dan pekerja terampil (misalnya Orlando \& Pollack, 2000; Midgley, 2008; Tambunan, 2009a, b, 2010, 2015a, 2018; Yuhua, 2013; Das \& Mohiuddin, 2015; Fiseha \& Oyelana, 2015; Oyelana \& Adu, 2015; Shah \& Saurabh, 2015; Santos \& Moustafa; 2016; Thapa, 2016; Raghuvanshi, Agrawal \& Ghosh, 2017).

Terkait dengan kapasitas SDM, seperti diketahui bahwa pelaku UMKM memiliki tingkat pendidikan yang relatif rendah. Relatif rendahnya tingkat pendidikan berdampak terhadap kemampuan atau pengetahuan, sikap, dan perilaku pelaku UMKM untuk mengelola keuangan usahanya. 


\section{Elastisitas - Jurnal Ekonomi Pembangunan}

Vol. 2 No. 1, Maret 2020

$\begin{array}{ccc}\text { Konsekwensi } & \text { dari } & \text { rendahnya } \\ \text { pengetahun pelaku UMKM } & \text { mengakses }\end{array}$ lembaga keuangan mencerminkan rendahnya tingkat literasi keuangan. Literasi keuangan didefenisikan sebagai gabungan keahlian tentang pemahaman atau pengetahuan (knowledge), sikap (attitude) dan perilaku (behavior) penting dalam membuat keputusan keuangan dan akhirnya memahami cara pengelolan keuangan pribadi yang lebih baik (OECD, 2011). Lusardi (2014) menyatakan bahwa literasi keuangan terdiri dari sejumlah kemampuan dan pengetahuan mengenai keuangan yang dimiliki oleh seseorang untuk mampu mengelola atau menggunakan sejumlah uang untuk meningkatkan taraf hidupnya dan bertujuan untuk mencapai kesejahteraan. Literasi keuangan sangat terkait dengan perilaku, kebiasaan dan pengaruh dari faktor eksternal.

Penetrasi layanan keuangan di Indonesia, terutama layanan perbankan, dinilai masih cukup rendah, jika dibandingkan dengan rasio penduduk Indonesia. Merujuk pada hasil riset OJK (2016) tentang literasi keuangan, di Indonesia daadalah sebesar 29,6 persen. Sementara itu untuk indeks inklusi finansial pada tahun yang sama mencapai 67,8 persen. Terhadap ke dua besaran hasil riset OJK tersebut, pemerintah pada tahun 2019 ini menargetkan minimal 79 persen. Sedangkan Provinsi NTB berada pada urutan kedua terendah diantara 34 Provinsi, dengan literasi keuangan sebesar 21,5, artinya tingkat literasi diseluruh kabupaten dan kota di NTB literasi keuangan sebesar 21,5 persen. Secara faktual data tingkat literasi keuangan di Kota Mataram belum tersedia, dengan demikian literasi keuangan Kota Mataram diproksi oleh nilai literasi keuangan NTB.

Determinan atau faktor penentu yang mempengaruhi literasi keuangan adalah tingkat pendidikan, jenis kelamin dan tingkat pendapatan (OJK, 2014). Sedangkan menurut Keown (2011) determinan yang mempengaruhi literasi keuangan adalah jenis kelamin, usia, status keluarga, tingkat pendidikan, jenis pekerjaan, tempat tinggal, dan status imigrasi.

Temuan Atkinson, (2012); Grohmann (2018) mengungkapkan bahwa determinan sosio-demografi menunjukkan bahwa perempuan memiliki tingkat literasi keuangan yang jauh lebih rendah daripada laki-laki di hampir semua negara. Klapper (2015) Wanita memiliki keterampilan keuangan yang lebih lemah daripada pria bahkan mempertimbangkan variasi dalam usia, negara, pendidikan, dan pendapatan. Terdapat hubungan positif antara pendidikan dan literasi keuangan. Individu yang berpendidikan lebih tinggi lebih cenderung menunjukkan perilaku dan sikap positif serta menunjukkan tingkat literasi yang lebih tinggi.

Penelitian ini melengkapi studi yang dilakukan (OJK, 2014) dan Keown (2011) diperluas dengan menambah indikator geografis. Maka determinan yang mempengaruhi literasi keuangan pada pelaku UMKM di kota Mataram adalah indikator tingkat pendidikan, usia, jenis kelamin, pendapatan, dan jarak domisili.

\section{a. Rumusan Masalah}

Berdasarkan latar belakang maka rumusan masalah dalam penelitian ini adalah.

1) Apakah tingkat pendidikan, usia, jenis kelamin, pendapatan, dan jarak domisili sebagai determinan yang mempengaruhi literasi keuangan pelaku UMKM di Kota Mataram?.

2) 1.2.2 Apakah Pengetahuan, sikap, dan perilaku sebagai indikator yang mempengarhi Literasi Keuangan pelaku UMKM di Kota Mataram.

\section{b. Tujuan Penelitian}

Berdasarkan latar belakang, dan rumusan masalah maka tujuan penelitian ini adalah "untuk membuktikan bahwa tingkat pendidikan, usia, jenis kelamin, pendapatan, dan jarak domisili sebagai determinan yang mempengaruhi literasi keuangan pelaku UMKM di Kota Mataram?. 


\section{Elastisitas - Jurnal Ekonomi Pembangunan}

Vol. 2 No. 1, Maret 2020

\section{c. Manfaat Penelitian}

Hasil penelitian ini diperoleh bukti empiris mengenai tingkat literasi keuangan pelaku UMKM di Kota Mataram, sekaligus dijadikan sebagai pedoman dalam melaksanakan edukasi dan pengukuran kedalaman inklusi keuangan.

\section{TINJAUAN PUSTAKA}

a. Tinjauan Teoritis (Literature Review)

1) Definisi Literasi Keuangan

Menurut Otoritas Jasa Keuangan (OJK) tahun 2011, literasi keuangan adalah pengetahuan (knowledge), keyakinan (confidence), dan keterampilan (skill), yang mempengaruhi sikap (attitude) dan perilaku (behaviour) untuk meningkatkan kualitas pengambilan keputusan dan pengelolaan keuangan dalam rangka mencapai kesejahteraan.

Definisi lain menenai literasi keuangan seperti diungkapkan oleh Organization for Economic Cooperation and Development (OECD) yang mendeskripsikan mengenai literasi keuangan yang mengambil konsepsi dari beberapa penelitian terkait dengam gabungan keahlian tentang pemahaman atau pengetahuan (knowledge), sikap (attitude) dan perilaku (behavior) penting untuk membuat keputusan keuangan dan akhirnya mencapai keuangan pribadi yang baik (OECD, 2011).

2) Indikator Literasi Keuangan

Berdasarkan definisi di atas menurut OECD (2016) mengungkapkan bahwa dalam pengukuran terhadap literasi keuangan ditentukan oleh tiga komponen atau indikator, yaitu.

a) Financial knowledge; Indikator financial knowledge dalam terminologi ini adalah terkait dengan pengetahuan dasar-dasar keuangan, manajemen keuangan, kredit dan hutang, tabungan dan investasi, dan resiko, serta asuransi.

b) Financial behavior; Indikator financial behavior adalah terkait dengan perilaku dalam penyusunan anggaran, menghemat uang dan mengontrol uang, investasi dan pembayaran kewajiban tepat waktu.

c) Financial atittude; Indikator financial attitude adalah terkait dengan sikap terhadap uang, dan perencanaan masa depan.

Pengetahuan keuangan dapat diperoleh dari pendidikan formal dan sumber-sumber informal. Pendidikan formal ini seperti program sekolah tinggi atau kuliah, seminar, dan kelas pelatihan di luar sekolah. Sedangkan sumber-sumber informal dapat diperoleh dari lingkungan sekitar, seperti dari orang tua, teman, dan rekan kerja, maupun yang berasal dari pengalaman sendiri.

Pengetahuan keuangan telah terbukti memiliki dampak yang signifikan terhadap manajemen keuangan, dan lebih konsisten ketika berbagai macam kebijakan digunakan (Sarah, 2009). Hal ini dapat dijelaskan melalui cara seseorang mengelola keuangan pribadinya dan manajemen keuangan itu menjadi faktor utama yang berkontribusi terhadap kepuasan keuangan atau ketidakpuasan keuangan seseorang. Secara teoritis, pengetahuan keuangan tentang bagaimana pasar keuangan beroperasi harus menghasilkan individu yang membuat keputusanlebih efektif (Robb dan Woodyard, 2011).

Sikap Keuangan menurut Robbins dan Judge (2008: 92), sikap adalah pernyataan yang evaluatif baik yang menyenangkan maupun yang tidak menyenangkan terhadap objek, individu, dan peristiwa. Sikap memiliki 3 komponen utama yang terdiri dari:

a) Kognitif

b) Afektif (perasaan)

c) Perilaku atau tindakan

Pengertian sikap keuangan menurut Pankow (2003) sebagaimana dikutip oleh Ningsih dan Rita (2010) yaitu diartikan sebagai keadaan pikiran, pendapat, serta penilaian tentang keuangan yang diaplikasikan kedalam sikap.

Menurut Eagly dan Chaiken dalam Wawan dan Dewi (2010:20) mengemukakan bahwa sikap dapat diposisikan sebagai hasil 


\section{Elastisitas - Jurnal Ekonomi Pembangunan \\ Vol. 2 No. 1, Maret 2020}

evaluasi terhadap obyek sikap yang diekspresikan ke dalam proses-proses kognitif, afektif (emosi) dan perilaku. Menurut Jodi \& Phyllis (1998) dalam Rajna et al., (2011) Sikap keuangan adalah kecenderungan psikologis yang diekspresikan ketika mengevaluasi praktik manajemen keuangan yang direkomendasikan dengan beberapa tingkatan kesepakatan dan ketidaksepakatan.

Sikap keuangan bisa dianggap sebagai kecenderungan psikologis yang diungkapkan saat mengevaluasi praktik pengelolaan keuangan yang direkomendasikan dengan beberapa tingkat kesepakatan atau ketidaksepakatan (Parrotta dan Johnson, 1998). Sikap keuangan memainkan peran penting dalam menentukan perilaku keuangan seseorang (Davisdan Schumm, 1987; Shih dan Ke, 2014) dalam Miendan Thao. Sikap keuangan membentuk cara orang menghabiskan wa ktu,menyimpan, menimbun, dan membuang-buang uang (Furnham, 1984) dalam Mien dan Thao (2015).

Eagly dan Chaiken (1993) dalam Deyola (2014) menjelaskan bahwa sikap diwujudkan dalam respon perilaku. Oleh karena itu, masuk akal untuk mendefinisikan sikap keuangan sebagai variabel subsistem pribadi dan perilaku keuangan sebagai variabel subsistem manajerial. Sikap keuangan yang dimiliki oleh seseorang akan membantu individu tersebut dalam menentukan sikap dan berperilaku mereka dalam hal keuangan, baik dalam hal manajemen keuangan, penganggaran keuangan pribadi, atau bagaimana keputusan individu mengenai bentuk investasi yang akan diambil. Semakin positif sikap terhadap manajemen keuangan, dan besarnya pengetahuan keuangan, semakin banyak praktek manajemen keuangan yang dapat diterapkan (Jodi \& Phyllis, 1998) dalam Deyola (2014).

(3). Perilaku Keuangan

Perilaku manajemen keuangan dianggap sebagai salah satu konsep penting pada disiplin ilmu keuangan. Banyak definisi yang diberikan sehubungan dengan konsep ini, misalnya, Horne dan Wachowicz (2002) dalam Mien dan Thao (2015) mengusulkan perilaku manajemen keuangan sebagai penentuan, akuisisi, alokasi, dan pemanfaatan sumber daya keuangan.

Sedangkan secara keseluruhan Weston dan Brigham (1981) dalam Mien dan Thao (2015) menggambarkan perilaku manajemen keuangan sebagai suatu pengambilan keputusan keuangan, harmonisasi motif individu dan tujuan perusahaan. Dengan demikian, menurut Mien dan Thao (2015) manajemen keuangan berkaitan dengan efektivitas manajemen dana.

Ketiga komponen tersebut dihitung terlebih dahulu besaran indeksnya, sehingga bernilai kisaran antara 0 (tidak terliterasi) hingga 1 (terliterasi dengan baik). Teknik penyusunan indeks masing-masing komponen pada dasarnya mengikuti rumus sebagai berikut (Sakinah dan Mudakir, 2018).

$\mathrm{ILK}=\sum_{i=1}^{3} \operatorname{li}: \operatorname{li}\left(\frac{x i-M i n x i}{\max x i-M i n X i}\right.$

ILK Dimana : ILK :Indeks Literasi Keuangan

Ii : Indeks komponen ILK ke $1(\mathrm{i}=1,2,3)$

$\mathrm{Xi}$ : Nilai indikator komponen ILK ke 1

Max Xi : Nilai Maximum Xi

Min Xi : Nilai Minimum Xi

Rumus yang digunakan untuk menghitung indeks literasi keuangan setiap masyarakat adalah sebagai berikut:

$\mathrm{ILK}=\frac{\text { Indeks } x 1+\text { indeks } x 2+\text { inde } k s x 3}{3}$

Dimana : ILK : Indeks Literasi Keuangan Masyarakat

$\mathrm{X} 1$ : Indeks Pengetahuan Keuangan

X2: Indeks Sikap Keuangan

X3 : Indeks Perilaku Keuangan

Hasil dari indeks literasi keuangan masyarakat kemudian dibagi kedalam beberapa kategori berdasarkan rumus Penilaian Acuan Norma (PAN) yakni adalah penilaian yang dilakukan dengan mengacu pada norma kelompok atau nilai yang diperoleh individu dibandingkan dengan nilai- 


\section{Elastisitas - Jurnal Ekonomi Pembangunan}

Vol. 2 No. 1, Maret 2020

nilai individu yang lain dalam kelompok tersebut. Pedoman yang digunakan untuk mengubah skor mentah menjadi skor standar pada PAN berdasarkan rata-rata (mean) dan standar deviasi.

\section{3) Kriteria Pengukuran Literasi Keuangan}

Terkait dengan indikator pengetahuan terhadap literasi keuangan OJK sebagai lembaga keuangan memastikan pemahaman masyarakat dengan program strategi nasional literasi keuangan dengan mencanangkan tiga pilar utama berdasarkan indikator sebagai berikut (OJK, 2016).

a) Well literate $(21,84$ persen $)$ memiliki pengetahuan dan keyakinan tentang lembaga keuangan serta produk jasa keuangan, manfaat dan resiko, hak dan kewajiban terkait produk dan jasa keuangan serta memiliki keterampilan dalam menggunakan produk dan jasa keuangan.

b) Sufficient literate (75,69 persen), memiliki pengetahuan dan keyakinan tentang lembaga jasa kauangan serta produk dan jasa keuangan, manfaat dan resiko, hak dan kewajiban terkait produk jasa keuangan.

c) Less literate (2,06 persen) hanya memiliki pengetahuan tentang lembaga jasa keuangan, produk dan jasa keuangan.

d) Not literate $(0,41$ persen), tidak memiliki pengetahuan dan keyakinan terhadap lembaga keuangan, dan jasa keuangan, serta tidak memiliki keterampilan dalam menggunakan produk dan jasa keuangan.

4) Definisi Usaha Miko, Kecil, dan Menengah (UMKM)

UKM atau yang biasa dikenal dengan usaha kecil menengah merupakan sebuah istilah yang mengacu pada suatu jenis usaha yang didirikan oleh pribadi dan memiliki kekayaan bersih paling banyak Rp 200.000.000, kekayatan tersebut belum termasuk tanah, dan bangunan (Nayla, 2014).

Sedangkan menurut Undang-Undang No.20 Tahun 2008, definisi UMKM adalah:
(1) Usaha mikro adalah usaha produktif milik orang perorangan dan/atau badan usaha perorangan yang memenuhi kriteria usaha mikro sebagaimana diatur dalam undang-undang ini.

(2) Usaha kecil adalah usaha ekonomi produktif yang berdiri sendiri, yang dilakukan oleh orang perorangan atau badan usaha yang bukan merupakan anak perusahaan atau bukan cabang perusahaan yang dimiliki, dikuasai, atau menjadi bagian baik langsung maupun tidak langsung dari usaha menengah atau usaha besar yang memenuhi kriteria usaha kecil sebagaimana dimaksud dalam undang-undang ini.

(3) Yang dimaksud usaha kecil dan menengah adalah kegiatan usaha dengan skala aktivitas yang tidak terlalu besar, manajemen masih sangat sederhana, modal yang tersedia terbatas, pasar yang dijangkau juga belum luas.

(4) Usaha menengah adalah usaha ekonomi produktif yang berdiri sendiri, yang dilakukan oleh orang perseorangan atau badan usaha yang bukan merupakan anak perusahaan atau cabang perusahaan yang dimiliki, dikuasai, atau menjadi bagian baik langsung maupun tidak langsung dengan usaha kecil atau usaha besar dengan jumlah kekayaan bersih atau hasil penjualan tahunan sebagaimana diatur dalam undang-undang ini. Dunia usaha adalah usaha mikro, usaha kecil, usaha menengah, dan usaha besar yang melakukan kegiatan ekonomi di Kota Mataram dan berdomisili di Kota Mataram.

(5) Kata lain dari pelaku usaha adalah wirausahawan (entrepreneuship). Secara sederhana, wirausahawan (entrepreneuship) dapat diartikan sebagai pengusaha yang mampu meliat peluang dengan mencari dana serta sumber daya lain yang diperlukan untuk menggarap peluang tersebut, berani menanggung risiko yang berkaitan dengan pelaksanaan bisnis yang ditekuninya, serta 
menjalankan usaha tersebut dengan rencana pertumbuhan dan ekspansi.

5) Kriteria Usaha Kecil dan Menengah Berdasar Perkembangan

Selain berdasar Undang-undang tersebut, dari sudut pandang perkembangannya Rahmana (2008) mengelompokkan UMKM dalam beberapa kriteria, yaitu:

a) Livelihood Activities, merupakan Usaha Kecil Menengah yang digunakan sebagai kesempatan kerja untuk mencari nafkah, yang lebih umum dikenal sebagai sektor informal. Contohnya adalah pedagang kaki lima.

b) Micro Enterprise, merupakan Usaha Kecil Menengah yang memiliki sifat pengrajin tetapi belum memiliki sifat kewirausahaan.

c) Small Dynamic Enterprise, merupakan Usaha Kecil Menengah yang telah memiliki jiwa kewirausahaan dan mampu menerima pekerjaan subkontrak dan ekspor

d) Fast Moving Enterprise, merupakam Usaha Kecil Menengah yang telah memiliki jiwa kewirausahaan dan akan melakukan transformasi menjadi Usaha Besar (UB).

\section{b. Penelitian Terdahulu (Empirical Review)}

Akhtar, Shamim (2018). Pengusaha UMKM dan Literasi Keuangan; Apakah Literasi Keuangan Benar-benar Penting? Tujuan dari penelitian ini adalah untuk menguji tingkat literasi keuangan pengusaha UKM dan pengaruhnya terhadap kinerja perusahaan. Penelitian ini menggunakan sampel acak dan pendekatan pemodelan persamaan struktural dalam mengukur dampak tingkat 'literasi keuangan pemilik atau manajer UKM di Pakistan. Hasil penelitian mengungkapkan bahwa pengaruh dari sikap keuangan pengusaha UKM, pengetahuan keuangan dan kesadaran keuangan dalam mengadaptasi literasi keuangan untuk meningkatkan kinerja perusahaan. Temuan lain menunjukkan bahwa kesadaran keuangan dan pengetahuan keuangan pengusaha UKM bukan prasyarat terhadap kinerja UKM, namun strategi usaha dalam membuat keputusan dan hubungan dengan sikap keuangan berbeda dengan literasi keuangan. Dengan demikian hasil temuan akan sangat berharga bagi pemilik, investor, dan penyedia layanan UKM.

Rasyid, Rosyeni, dkk (2018) dalam penelitiannya Analisis Literasi Keuangan dan Keuangan Inklusi Sebagai Strategi untuk Meningkatkan Daya Saing Usaha Kecil Menengah (UKM) Pada Usaha Kerajinan Tangan Di Sumatera Barat. Tujuan dari penelitian ini adalah untuk menemukan tingkat literasi keuangan dan inklusi keuangan pengusaha kerajinan, serta untuk melihat korelasi antara tingkat literasi keuangan dengan tingkat inklusi keuangan, dan untuk mengidentifikasi faktor-faktor yang menghambat perkembangan. Inklusi keuangan. Penelitian ini menggunakan observasi lapangan, wawancara, dan distribusi kuesioner sebagai data primer, dan data sekunder diperoleh dari instansi terkait. Untuk menjawab pertanyaan penelitian, digunakan metode analisis deskriptif dan pemodelan persamaan struktural. Hasil penelitian menunjukkan bahwa literasi keuangan memiliki dampak positif dan signifikan terhadap inklusi keuangan pengusaha kerajinan, tingkat literasi keuangan sampel dikategorikan cukup literate, dan inklusi keuangan pengusaha kerajinan juga dikategorikan cukup. Oleh karena itu, perlu untuk mengembangkan inklusi keuangan dengan mengatasi hambatan yang dihadapi oleh UKM, terutama dalam mengakses layanan perbankan dan lembaga keuangan formal lainnya untuk meningkatkan daya saing UKM.

Widiyati (2018) dalam penelitiannya yang berjudul Financial Literacy Model at Micro Small Medium Entreprise (MSMEs). Penelitian tersebut bertujuan untuk mengukur tingkat literasi keuangan UMKM dan menentukan korelasinya dengan variabel demografis dan ekonomi serta merancang 


\section{Elastisitas - Jurnal Ekonomi Pembangunan}

Vol. 2 No. 1, Maret 2020

model untuk meningkatkan literasi. Hasil penelitian menunjukkan bahwa $51(25,5 \%)$ pelaku UMKM memiliki tingkat literasi yang rendah, $105(52,5 \%)$ memiliki tingkat sedang, dan sisanya 44 (22\%) memiliki tingkat literasi yang tinggi. Koefisien Kontingensi kurang dari 0,6 menunjukkan bahwa korelasi demografi dan sosial ekonomi kurang kuat dalam tingkat literasi. Hasil analisis menunjukkan ada tiga faktor yang membentuk model literasi keuangan: pertama adalah sikap keuangan; kedua adalah pengetahuan keuangan, dan yang ketiga adalah perilaku keuangan.

Abubakar, Habib Auwal, (2015). Penelitiannya yang berjudul Pengembangan Kewirausahaan dDan Literasi Keuangan Di Afrika. Studi ini secara khusus melihat bagaimana literasi keuangan mempengaruhi perilaku rumah tangga mengenai pengambilan keputusan keuangan, serta kesenjangan gender dalam literasi keuangan. Karena literasi keuangan mendapatkan momentum baik di negara maju dengan sistem keuangan yang canggih dan negara berkembang dengan tingkat layanan keuangan yang rendah, penelitian ini berupaya untuk membangun hubungan formal antara literasi keuangan dan akses ke keuangan dan apa dampak keduanya bagi pengembangan masyarakat kewirausahaan di Afrika. Ini juga berfokus pada hubungan antara pengambilan keputusan keuangan dan gender serta akses ke keuangan dengan tujuan memeriksa dengan seksama implikasi pada pengembangan kewirausahaan. Hasil penelitan menunjukkan bahwa kesulitan dalam akses ke keuangan, akses ke pasar, dukungan kebijakan dan budaya kewirausahaan adalah masalah utama dan kendala pada pengembangan kewirausahaan di Afrika yang memiliki implikasi yang sangat kuat untuk literasi keuangan terutama pada usaha mikro, kecil dan menengah. Masalah penting lainnya termasuk iklim investasi yang tidak menguntungkan, tidak adanya program pelatihan kewirausahaan, lingkungan bisnis investasi yang tidak ramah, kesenjangan gender dan kurangnya rantai nilai dalam ekosistem kewirausahaan.

Fatoki (2014) meneliti tingkat literasi keuangan pemilik UMKM baru di Afrika Selatan. Penelitian ini menggunakan perencanaan keuangan, analisis dan kontrol pembukuan, sumber pendanaan, terminologi bisnis, keterampilan keuangan dan informasi, penggunaan teknologi dan manajemen risiko untuk mengukur literasi keuangan pemilik usaha. Data dikumpulkan melalui penggunaan kuesioner yang dikelola sendiri dalam survei. Kombinasi pertanyaan menggunakan skala dikotomi dan Likert. Analisis data menggunakan statistik deskriptif, hasilnya menunjukkan bahwa tingkat literasi keuangan adalah rendah pada pemilik UMKM baru.

Mabula, Juma Buhimila, (2013). Tinjauan Literasi Keuangan untuk UKM dan Pengusaha di Negara Berkembang. Seiring meningkatnya studi literasi keuangan di dunia, kekhawatiran terhadap perkembangan ekonomi semakin meningkat. Studi ini mencoba meninjau literasi keuangan untuk UKM dan pengusaha di negara berkembang dalam dekade terakhir. Ulasan ini mengungkapkan kelangkaan literatur tentang fenomena ini. Ada perbedaan besar dalam konten pengukuran domain keuangan, metodologi dan kerangka sampling. Semua ini menyerukan intervensi segera oleh para peneliti, pemerintah, lembaga keuangan, dan institusi bilateral yang berurusan dengan berbagai inisiatif literasi keuangan. Seperti halnya literasi umum, perkembangan ekonomi memiliki rentang waktu yang cukup lama untuk mewujudkan pencapaian penting terhadap literasi keuangan. Lebih banyak upaya yang dilaksanakan oleh pemerintah untuk menghasilkan inisiatif untuk menyadarkan pentingnya literasi keuangan. Pemerintah perlu bekerja sama dengan lembaga ekonomi bilateral dan organisasi internasional seperti Finescope dan Worldbank yang telah melakukan banyak penelitian dan melembagakan banyak inisiatif terhadap individu dan kesadaran keuangan perusahaan. Dengan kerangka kerja 


\section{Elastisitas - Jurnal Ekonomi Pembangunan}

Vol. 2 No. 1, Maret 2020

kelembagaan yang kondusif, sektor swasta terutama lembaga keuangan dapat mencapai banyak literasi keuangan dengan menawarkan pelatihan, yang terkait dengan produk yang mereka tawarkan ke pasar.

Sucuahi, William T, (2013). Faktor Penentu Literasi Keuangan pada Pengusaha Mikro Di Kota Davao. Studi ini menentukan literasi keuangan pengusaha mikro di Kota Davao. Sebanyak 100 pengusaha mikro berpartisipasi dalam penelitian ini. Secara keseluruhan, tingkat literasi keuangan para wirausahawan mikro adalah moderat yang menunjukkan manajemen keuangan sumber daya mereka yang tidak begitu mengesankan. Untuk mendapatkan faktor-faktor penentu literasi keuangan, digunakan analisis regresi berganda yang mengungkapkan pengaruh signifikan dari tingkat pendidikan terhadap literasi keuangan. Namun hasilnya menunjukkan bahwa gender tidak dapat memprediksi tingkat literasi keuangan di kalangan pengusaha mikro.

Atkinson, et al (2012), penelitiannya berjudul "Measuring Financial Literacy: Results of the OECD/International Network on Financial Education (INFE) Pilot Study". Temuan analisis dengan menggunakan indikator sosio-demografi menunjukkan bahwa perempuan memiliki tingkat pengetahuan keuangan yang jauh lebih rendah daripada laki-laki di hampir semua negara yang diteliti. Jadi misalnya, 67 persen pria di Inggris memperoleh skor 6 atau lebih untuk ukuran pengetahuan, sedangkan hanya 40 persen wanita mencapai skor dengan indikator pengukuran yang sama.

Oseifuang (2010) dalam penelitiannya yang berjudul Financial literacy and youth entrepreneurship in South Africa. Untuk mengukur tingkat literasi keuangan penelitian ini menggunakan tanggapan pada literasi matematika, literasi komputer, sikap keuangan, pengetahuan dan perilaku keuangan. Hasil penelitian menunjukkan bahwa 51 persen responden memiliki tingkat literasi matematika di atas rata-rata dan untuk 61 persen responden tingkat literasi komputer berada di atas rata-rata. Berdasarkan hasil penelitian disimpulkan bahwa tingkat literasi keuangan di kalangan wirausahawan muda di Distrik Vhembe Afrika Selatan di atas ratarata, namun peneliti mengakui bahwa sampel yang digunakan dalam penelitian ini terlalu kecil, oleh karena itu hasilnya tidak dapat digeneralisasi, serta diperlukan penelitian lebih lanjut untuk menilai tingkat literasi keuangan di kalangan pengusaha muda dan konsumen lain secara umum.

\section{Metode Penelitian \\ a. Jenis Penelitian}

Jenis penelitian yang digunakan adalah penelitian eksplanasi. Penelitian eksplanasi mengkaji hubungan sebab-akibat di antara dua fenomena atau lebih. Penelitian seperti ini dipakai untuk menentukan apakah suatu eksplanasi (keterkaitan sebab-akibat) valid atau tidak, atau menentukan mana yang lebih valid di antara dua (atau lebih) eksplanasi yang saling bersaing.

\section{b. Lokasi dan Waktu Penelitian}

Lokasi penelitian ini dilakukan di Kota Mataram yang meliputi 6 Kecamatan, yakni Kecamatan Mataram, Ampenan, Cakranegara, Sekarbela, Selaparang, dan Sandubaya. Adapun waktu penelitian atau pengumpulan data diharapkan pada bulan September 2019.

\section{c. Metode dan Teknik Pengumpulan Data}

Metode pengumpulan data dalam penelitian ini mengambil sampel dari sebagian populasi pada pelaku UMKM di Kota Mataram adalah melalui metode sampel survey. Adapun teknik pengumpulan data melalui tahapan studi pustaka, observasi, dan wawancara langsung dengan resoponden yang berpedoman pada daftar pertanyaan atau kuisioner yang disusun oleh peneliti.

\section{d. Teknik Pengambilan Sampel}

Proses seleksi sampel yang digunakan dalam penelitian dari populasi pelaku UMKM yang ada di Kota Mataram adalah menggunakan probability random sampling, berdasarkan kluster sampling. Penentuan sampel terpilih ditentukan dengan menggunakan Tabel Angka Random (TAR). 


\section{e. Populasi, dan Besarnya Sampel}

Populasi dalam penelitian ini adalah keseluruhan pelaku UMKM yang tersebar di enam (6) kecamatan di Kota Mataram. Atas pertimbangan heterogenitas dan cakupan wilayah maka jumlah sampel ditentukan sebanyak 105 pelaku UMKM. Proses randomisasi berdasarkan jenis usaha UMKM, jumlah sampel responden dialokasikan sebagai berikut.

Tabel 3.1 Jumlah Sampel Responden Berdasarkan Wilayah dan Jenis Usaha Pelaku UMKM di Kota Mataram.

\begin{tabular}{|c|c|c|c|c|c|}
\hline \multirow[t]{2}{*}{ No } & \multirow[t]{2}{*}{ Kecamatan } & \multicolumn{3}{|c|}{$\begin{array}{c}\text { Jumlah sampel menurut jenis usaha pelaku } \\
\text { UMKM (orang) }\end{array}$} & \multirow[t]{2}{*}{ Jumlah } \\
\hline & & Mikro & Kecil & Menengah & \\
\hline 1 & Mataram & 10 & 10 & 10 & 30 \\
\hline 2 & Ampenan & 5 & 5 & 5 & 15 \\
\hline 3 & Cakranegara & 5 & 5 & 5 & 15 \\
\hline 4 & Sekarbela & 5 & 5 & 5 & 15 \\
\hline 5 & Selaparang & 5 & 5 & 5 & 15 \\
\hline 6 & Sandubaya & 5 & 5 & 5 & 15 \\
\hline & Total & 35 & 35 & 35 & 105 \\
\hline
\end{tabular}

\section{f. Klasifikasi dan Definisi Operasional Variabel}

1) Klasifikasi Variabel

Variabel di dalam penelitian ini terdiri dari variabel endogen dan variabel eksogen. Variabel endogen (dependen variable), yaitu literasi keuangan pelaku UMKM (Y). Sedangan variabel eksogen (independen variable) terdiri dari 5 indikator yakni, tingkat pendidikan, usia, jenis kelamin, pendapatan, dan jarak domisi pelaku UMKM terhadap lembaga keuangan.

2) Definisi Operasional Variabel

Berdasarkan klasisifikasi variabel baik variabel endogen $(\mathrm{Y})$ maupun variabel eksogen (Xi) seperti yang dijelaskan sebelumnya, maka definisi operasional variabelnya dirinci sebagai berikut.

a) Tingkat pendidikan (X1), merupakan jenjang pendidikan yang pernah dicapai oleh responden secara formal, diukur dalam satuan tahun. Indikator tingat pendidikan diukur dalam skala interval.

b) Umur (X2), adalah jumlah tahun yang telah dijalani responden dihitung sejak kelahiran sampai saat penelitian dilaksanakan, diukur dalam satuan tahun. Adapun skala pengukuran indiktor umur adalah dalam skala ratio.

c) Jenis Kelamin (X3), jenis kelamin responden laki dan perempuan. Laki diberi skor 1, dan perempuan diberi skor 0. Adapun skala pengukuran indiktor jenis kelami adalah dalam skala nominal.

d) Jumlah Pendapatan (X4) merupakan total pendapatan yang diperoleh responden dinyatakan dalam rupiah selama satu bulan. Indikator jumlah pendapatan responden diukur dalam skala interval.

e) Jarak domisili (X5), merupakan jarak tempuh oleh responden dari tempat usaha ke pusat lembaga keuangan, diukur dengan dalam satuan kilometer $(\mathrm{Km})$. Indikator jarak domisili responden diukur dalam skala rasio.

f) Literasi Keuangan (Y) merupakan penjumlahan penilaian terhadap ke 3 dimensi yakni pengetahuan, sikap, dan perilaku responden (pelaku UMKM). Indikator literasi keuangan responden diukur dalam skala interval.

\section{g. Metode dan Model Analisis Data}

Berdasarkan uraian latar belakang, rumusan masalah, tujuan penelitian dan 


\section{Elastisitas - Jurnal Ekonomi Pembangunan \\ Vol. 2 No. 1, Maret 2020}

rumusan hipotesis, maka model analisis yang digunakan dalam penelitian ini akan dilakukan dengan metode estimasi dan pengujian hipotesis menggunakan model analisis jalur Partial Least Squares (PLS).

Model analisis jalur semua variabel laten dalam PLS terdiri dari tiga hubungan (Ghozali, 2006, 22).

a) Inner model yang menspesifikasikan hubungan antar variabel laten (struktural model)

b) Outer model yang menspesifikasikan hubungan antar variabel laten dengan indikator atau variabel manifestnya (measurement model)

c) Weight relation dalam mana nilai kasus dari variabel laten dapat diestimasi.

1) Langkah 1 : Merancang inner model Inner model (inner relation, structural model dan substantative theory), model persamaannya dapat ditulis sebagai berikut :

$\mathrm{\eta}=\beta 0+\beta \mathrm{\eta}+\Gamma^{\prime} \xi+\zeta$

dimana :

$\mathrm{y}=$ Vektor variabel endogen (dependen) variabel laten

$\xi=$ Vektor variabel laten eksogen (independen) variabel laten

$\zeta=$ Vektor variabel residual (unexplained variance).

Karena PLS didisain untuk model rekursive, maka hubungan antar variabel laten, setiap variabel laten dependen $y$ atau sering disebut causal chain system dari variabel laten, dengan spesifikasi berikut: $\mathrm{y}=\Sigma \mathrm{i} \beta \mathrm{ji} \mathrm{ji}+\Sigma \mathrm{i} \lambda \mathrm{jb} \xi \mathrm{b}+\zeta \mathrm{j}$

2) Langkah ke 2 : Merancang outer model (outer relation, measurement model), persamaannya sebagai berikut:

$\mathrm{X}=\Lambda \mathrm{x} \xi+\zeta \mathrm{x}$

$\mathrm{Y}=\Lambda \mathrm{y} \mathrm{y}+\zeta \mathrm{y}$

dimana :
$\mathrm{X}$ dan $\mathrm{y}=$ indikator atau manifest variabel untuk variabel laten eksogen dan endogen ( $\xi$ dan $\eta$ )

$\Lambda \mathrm{y}$ dan $\Lambda \mathrm{x}=$ merupakan matrik loading yang menggambarkan koefisien regresi sederhana yang menghubungkan variabel laten dengan indikatornya.

$\mathrm{Zx}$ dan $\zeta \mathrm{y}=$ residual yang diintepretasikan sebagai kesalahan pengukuran atau noise.

3) Langkah ke-3: Mengkonstruksi diagram jalur, seperti nampak dalam gambar

4) Langkah ke-lima : pendugaan parameter yang diperoleh melalui PLS meliputi 3 kategori, yaitu : Weight estimate, path estimate, dan loading. (Solimun, 2007:10)

5) Langkah ke-enam : Evaluasi model pengukuran, meliputi : outer model, dan Evaluasi model struktural (inner model)

6) Langkah ke-7 : Pengujian Hipotesis (Solimun, 2007:12)

a) Hipotesis statistik untuk outer model:

- $\mathrm{H} 0: \lambda \mathrm{i}=0$

- $\mathrm{H} 1: \lambda \mathrm{i} \neq 0$

b) Hipotesis statistik untuk inner model: variabel laten eksogen terhadap endogen:

- $\mathrm{H} 0: \gamma \mathrm{i}=0$

- $\mathrm{H} 1: \gamma \mathrm{i} \neq 0$

c) Pengujian dilakukan dengan t-test; p-value $\leq 0,05$ (alpha $5 \%$ ); adalah signifikan

d) Pada outter model signifikan: maka dapat digunakan sebagai instrumen pengukur variabel laten.

e) Pada inner model adalah signifikan, maka dapat diartikan bahwa terdapat pengaruh yang bermakna suatu variabel laten terhadap variabel laten lainnya. 


\section{Elastisitas - Jurnal Ekonomi Pembangunan \\ Vol. 2 No. 1, Maret 2020}

\section{Hasil dan Pembahasan}

a. Hasil Pengujian dan Hubungan Antar Konstruk

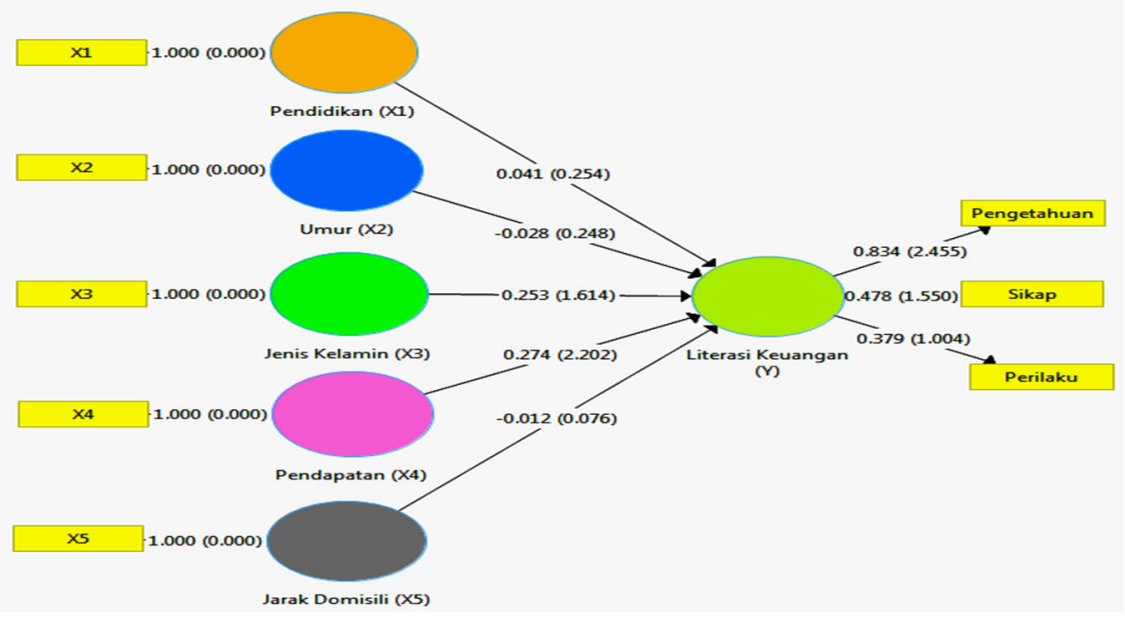

1) Pengujian Nilai Inner Loadings

Tabel 4.1 Nilai Mean, Standar Deviasi, t Statistik, dan p-Value Masing-masing Konstruk dalam Inner Model

\begin{tabular}{|l|r|r|r|r|r|}
\hline \multicolumn{1}{|c|}{ Inner Loading } & $\begin{array}{c}\text { Original } \\
\text { Sample (O) }\end{array}$ & $\begin{array}{c}\text { Sample } \\
\text { Mean (M) }\end{array}$ & $\begin{array}{c}\text { Standard } \\
\text { Deviation } \\
\text { (STDEV) }\end{array}$ & $\begin{array}{c}\text { t Statistics } \\
\text { (|O/STDEV|) }\end{array}$ & P Values \\
\hline $\begin{array}{l}\text { Pendidikan (X1) -> } \\
\text { Literasi Keuangan (Y) }\end{array}$ & 0.041 & 0.065 & 0.163 & 0.254 & 0.800 \\
\hline $\begin{array}{l}\text { Umur (X2) -> } \\
\text { Literasi Keuangan (Y) }\end{array}$ & -0.028 & -0.003 & 0.112 & 0.248 & 0.804 \\
\hline $\begin{array}{l}\text { Jenis Kelamin (X3) -> } \\
\text { Literasi Keuangan (Y) }\end{array}$ & 0.253 & 0.223 & 0.157 & 1.614 & 0.107 \\
\hline $\begin{array}{l}\text { Pendapatan (X4) -> } \\
\text { Literasi Keuangan (Y) }\end{array}$ & 0.274 & 0.250 & 0.124 & $\mathbf{2 . 2 0 2}$ & $\mathbf{0 . 0 2 8}$ \\
\hline $\begin{array}{l}\text { Jarak Domisili (X5) -> } \\
\text { Literasi Keuangan (Y) }\end{array}$ & -0.012 & 0.011 & 0.152 & 0.076 & 0.939 \\
\hline
\end{tabular}

Sumber : data primer diolah

Berdasarkan hasil yang terdapat dalam tabel di atas dapat dijelaskan sebagai berikut.

Hipotesis pertama (H1), menyatakan bahwa Pendidikan berpengaruh terhadap Literasi Keuangan pelaku UMKM di Kota Mataram adalah tidak terbukti (tidak signifikan), hal tersebut didukung oleh nilai $\mathrm{t}$ statistiknya yaitu sebesar 0,254 adalah lebih kecil jika dibandingan nilai t tabel pada $\alpha: 5$ persen 1,96 atau dengan nilai $p$-values 0,800 (nilai p-values lebih besar dari 0,05).Dengan demikian dapat disimpulkan bahwa hipotesis nol (H0) tidak ditolak, yang bermakna bahwa pendidikan tidak berpengaruh terhadap Literasi Keuangan pelaku UMKM di Kota Mataram

Hipotesis kedua $(\mathrm{H} 2)$, menyatakan bahwa usia atau umur berpengaruh terhadap Literasi Keuangan pelaku UMKM di Kota Mataram adalah tidak terbukti (tidak signifikan), hal tersebut didukung oleh nilai $\mathrm{t}$ statistiknya yaitu sebesar 0,248, adalah lebih besar jika dibandingan nilai $\mathrm{t}$ tabel pada $\alpha: 5$ persen 
1,96 atau dengan nilai $\mathrm{p}$-values 0,804 (nilai p-values lebih besar dari 0,05).Dengan demikian dapat disimpulkan bahwa hipotesis nol (H0) tidak ditolak, yang bermakna bahwa umur tidak berpengaruh terhadap Literasi Keuangan pelaku UMKM di Kota Mataram

Hipotesis ketiga (H3), menyatakan bahwa jenis kelamin berpengaruh terhadap Literasi Keuangan pelaku UMKM di Kota Mataram adalah tidak terbukti (tidak signifikan), hal tersebut didukung oleh nilai $\mathrm{t}$ statistiknya yaitu sebesar 1,614, adalah lebih kecil jika dibandingan nilai $t$ tabel pada $\alpha: 5$ persen 1,96 atau dengan nilai $p$-values 0,107 (nilai $p$-values lebih besar dari 0,05).Dengan demikian dapat disimpulkan bahwa hipotesis nol (H0) tidak ditolak, yang bermakna bahwa tidak terdapat perbedaan yang signifikan tingkat literasi antara perempuan dan laki-laki.

Hipotesis ke-empat (H4), menyatakan bahwa pendapatan berpengaruh terhadap Literasi Keuangan pelaku UMKM di Kota Mataram adalah terbukti (signifikan), hal tersebut didukung oleh nilai t statistiknya yaitu sebesar 2.202, adalah lebih besar jika dibandingan nilai $\mathrm{t}$ tabel pada $\alpha$ : 5 persen 1,96 atau dengan nilai p-values 0,028 (nilai $p$-values lebih kecil dari 0,05).Dengan demikiandapat disimpulkan bahwa hipotesis nol (H0) ditolak atau Ha diterima, yang bermakna bahwa pendapatan berpengaruh terhadap Literasi Keuangan pelaku UMKM di Kota Mataram

Hipotesis ke-lima

(H5), menyatakan bahwa jarak domisili berpengaruh terhadap Literasi Keuangan pelaku UMKM di Kota Mataram adalah tidak terbukti (tidak signifikan), hal tersebut didukung oleh nilai t statistiknya yaitu sebesar 0,076, adalah lebih kecil jika dibandingan nilai t tabel pada $\alpha: 5$ persen 1,96 atau dengan nilai $p$-values 0,939 (nilai p-values lebih besar dari 0,05). Dengan demikian dapat disimpulkan bahwa hipotesis nol (H0) tidak ditolak, yang bermakna bahwa jarak domisili tidak berpengaruh terhadap Literasi Keuangan pelaku UMKM di Kota Mataram.

\section{2) Pengujian Nilai Outer Loadings}

Tabel 4.2 Nilai Mean, Standar Deviasi, t Statistik, dan p-Value Masing-masing Indikator dalam Outer Model

\begin{tabular}{|l|c|c|c|c|c|}
\hline \multicolumn{1}{|c|}{ Outer Loading } & $\begin{array}{c}\text { Original } \\
\text { Sample (O) }\end{array}$ & $\begin{array}{c}\text { Sample } \\
\text { Mean (M) }\end{array}$ & $\begin{array}{c}\text { Standard } \\
\text { Deviation } \\
\text { (STDEV) }\end{array}$ & $\begin{array}{c}\text { T Statistics } \\
(\mid \mathbf{O} / \text { STDEV|) }\end{array}$ & P Values \\
\hline $\begin{array}{l}\text { Pengetahuan <- Literasi Keuangan } \\
\text { (Y) }\end{array}$ & 0.847 & 0.635 & 0.338 & $\mathbf{2 . 5 0 5}$ & $\mathbf{0 . 0 1 3}$ \\
\hline Sikap <- Literasi Keuangan (Y) & 0.498 & 0.391 & 0.261 & 1.904 & 0.057 \\
\hline Perilaku <- Literasi Keuangan (Y) & 0.146 & 0.246 & 0.368 & 0.397 & 0.691 \\
\hline
\end{tabular}

Sumber : data primer diolah

(3) dimensi atau indikator yakni pengetahuan, sikap, dan perilaku keuangan. Untuk menjawab hipotesis keenam (H6), H7 dan H8, bahwa ke tiga indikator tersebut berpengaruh terhadap literasi keuangan tidak terbukti, kecuali
H6. Nilai t statistik pada H6 adalah sebesar 2,505 lebih besar jika dibandingan nilai $\mathrm{t}$ tabel pada $\alpha: 5$ persen 1,96 atau dengan nilai p-values 0,013 (nilai p-values lebih kecil dari 0,05). Dengan demikian dapat disimpulkan bahwa $\mathrm{H} 0$ ditolak atau $\mathrm{Ha}$ diterima, yang bermakna bahwa 
pengetahuan sebagai indikator penentu terhadap Literasi Keuangan. Namun secara keseluruhan bahwa pengetahuan, sikap, dan perilaku kurang valid sebagai pengukur literasi keuangan.

3) Pengujian Nilai the Goodness of Fit

Tabel 4.3 Nilai R-Square

\begin{tabular}{|l|c|c|c|c|c|}
\hline & $\begin{array}{c}\text { Original } \\
\text { Sample (O) }\end{array}$ & $\begin{array}{c}\text { Sample } \\
\text { Mean (M) }\end{array}$ & $\begin{array}{c}\text { Standard } \\
\text { Deviation } \\
\text { (STDEV) }\end{array}$ & $\begin{array}{c}\text { T Statistics } \\
(\mid \mathbf{O} / \text { STDEV } \mid)\end{array}$ & P Values \\
\hline Literasi Keuangan (Y) & 0.139 & 0.207 & 0.058 & 2.421 & 0.016 \\
\hline
\end{tabular}

Sumber : data primer diolah

Berdasarkan tabel 4.3 diketahui bahwa nilai R-square (nilai original sampel) adalah sebesar 0,139. Nilai R-square tersebut menandakan bahwa hasil estimasi berdasarkan inner dan outer model menyangkut variabel pendidikan, umur, jenis kelamin, pendapatan dan jarak domisili, serta indikator pengetahuan, sikap, dan perilaku terhadap literasi keuangan adalah predictive relevan. Predictive relevan seluruh variabel dan indikator pembentuk literasi keuangan dibuktikan oleh nilai $\mathrm{t}$ statistik sebesar 2,241, dengan nilai p-value sebesar 0,016 (lebih kecil dari 0,05). Hasil pembuktian tersebut bermakna bahwa tingkat literasi keuangan pelaku usaha UMKM dapat dijelaskan oleh pendidikan, umur, jenis kelamin, pendapatan dan jarak domisili, serta indikator pengetahuan, sikap, dan perilaku adalah sebesar 13,9 persen. Adapun 86,1 persen literasi keuangan antara lain ditentukan sumber permodalan, skala usaha, pengalaman berusaha, penggunaan teknokogi, pemasaran produk dari pelaku usaha UMKM di Kota Mataram.

4) Pengujian Average Variance Extracted (AVE)

Berdasarkan pengolahan data diperoleh hasil pengujian AVE yang ditunjukkan oleh nilai $\mathrm{t}$ statistik sebesar 6,903 dengan p-value sebesar 0,000 (lebih kecil 0,05). Hasil pengujian terhadap AVE tersebut dapat disimpulkan bahwa ke-5 variabel bebas yakni adalah konsisten sebagai determinan yang mempengaruhi literasi keuangan pelaku usaha UMKM di Kota Mataram.

Tanda dan nilai parameter konstruk pendidikan adalah positif, maknanya bahwa semakin tinggi pendidikan pelaku usaha UMKM maka akan berdampak terhadap beberapa dimensi literasi seperti pengetahuan, sikap dan perilaku keuangan. Oleh karena itu faktor pendidikan akan mengakibatkan luasnya pemahaman pelaku usaha UMKM terhadap literasi keuangan.

Demikian juga dengan tanda dan nilai parameter konstruk umur, dan pendapatan, keduanya adalah bertanda positif. Maknanya adalah seiring dengan bertambah umur dan tingkat pendapatan pemilik usaha UMKM akan mengakibatkan semakin bertambahnya pengetahuan terhadap dimensi keuangan (melek keuangan).

Adapun tanda dan nilai parameter konstruk jarak domisili adalah negatif, maknanya bahwa semakin jauh jarak domisili pelaku usaha UMKM dengan lembaga keuangan maka akan semakin rendah aspek pengetahuan, sikap dan perilaku keuangan, atau dengan kata lain tingkat literasi keuangan pelaku usaha UMKM dikategorikan rendah .

Satu-satunya faktor yang signifikin dan predictive relevan terhadap literasi keuanganadalah faktor umur pelaku usaha UMKM di Kota Mataram. Hal tersebut sangat menentukan fase-fase atau tahapan baik yang terkait dengan jenjang 
pendidikan (dimensi sikap dan pengetahuan keuangan), dan keberdayaan atau kemampuan seseorang yang dimanifestasi sebagai tingkat produktifitas pelaku usaha UMKM (dimensi perilaku keuangan).

\section{b. Pembahasan}

Tingkat literasi keuangan bervariasi menurut jenjang pendidikan seseorang, secara konseptual bahwa ada hubungan antara peningkatan tingkat pendidikan dan tingkat literasi keuangan seseorang. Seseorang yang berpendidikan lebih tinggi cenderung memiliki tingkat literasi keuangan yang tinggi dibandingakn dengan tingkat pendidikan sekolah menengah atas. Namun secara faktual dimungkinkan juga bahwa seseorang dengan tingkat pedidikan sekolah menengah atas literasi keuangannya diatas yang berpendidikan perguruan tinggi.

Dimasa-masa yang akan datang diharapkan literasi keuangan meningkat seiring bertambahnya usia atau umur seseorang, bertambahnya usia seseorang khususnya pelaku usaha UMKM cenderung menjadi lebih berpengetahuan, dan sikap serta perilaku mereka berubah sesuai. Namun, berdasarkan hasil penelitian faktor usia tidak berpengaruh signifikan terhadap literasi keuangan. Hal tersebut kemungkinan disebabkan adanya perbedaan tingkatan usia responden. Semakin tua seseorang semakin sulit untuk mengikuti laju perubahan informasi di pasar keuangan terutama pasar keuangan di era industri 4.0 penuh dengan muatan financialtechnology (fintech).

Berdasarkan fakta penelitian diketahui bahwa proporsi responden pria lebih besar daripada responden wanit, namun berdasarkan hasil pengujian diungkapkan tidak ada perbedaan yang signifikan antara proporsi pria dan wanita terhadap literasi keuangan, maknanya bahwa peningkatan pengetahuan antara laki-laki dan perempuan sama. Hal tersebut bertolak belakang dengan hasil penelitian sebelumnya yang mengungkapkan bahwa perempuan relatif rendah dalam hal literasi keuangan.

Berdasarkan hasil penelitian terungkap bahwa pendapatan berpengaruh terhadap literasi keuangan, artinya bahwa tingkat literasi keuangan yang tinggi dimungkinkan di semua tingkat pendapatan pelaku usaha UMKM di Kota Mataram. Hal tersebut dapat diartikan bahwa pendapatan memiliki dampak pada kemampuan seseorang untuk memperoleh pengetahuan, membentuk sikap yang kondusif bagi kesejahteraan finansial mereka. Namun sebaliknya, ketika tingkat pendapatan seseorang rendah sering dijadikan alasan untuk mendapatkan akses pelayanan keuangan.

Jika pendapatan dikaitkan dengan pendidikan dan umur, diperoleh gambaran bahwa tingkat pendapatan yang diperolah biasanya tersegmentasi berdasarkan tingkatan umur dan pendidikan. Dengan demikian akan berdampak juga terhadap tingkatan literasi keuangannya. Bagi UMKM yang termasuk dalam kategori golongan yang berpendapatan rendah biasanya menjadi prioritas dalam program pemberdayaan, baik aspek permodalan, maupun program-program lain seperti edukasi atau sosialisai cara mengakses layanan keuangan yang mudah dan efisien.

Bisanya seseorang dengan literasi keuangan akan memiliki pengetahuan dasar tentang konsep keuangan dan kemampuan untuk menerapkan keterampilan mengkalkulasi kondisi keuangan. Namun jika seseorang yang memiliki pengetahuan keuangan pada tingkatan yang tinggi, tidak selalu menunjukkan bahwa mereka adalah ahli dalam masalah-masalah keuangan.

Tidak dapat dipungkiri bahwa sikap keuangan sebagai salah satu dimensi yang cukup penting dari literasi keuangan. Jika 
orang memiliki sikap yang rendah terhadap hasrat untuk menabung, padahal hasil dari aktivitas menabung adalah untuk memperkuat ketahanan keuangannya. Demikian pula, jika orientasi seseorang lebih memprioritaskan keinginan jangka pendek, maka ketahanan keuangan yang ditopang oleh tabungan bisa teratasi oleh dana tabungan dalam jangka panjang. Dengan demikian dapat disimpulkan bahwa sikap keuangan yang bertumpu pada dana atau uang terkait dengan perencanaan keuangan untuk masa-masa yang akan datang dala jangka panjang.

Perilaku adalah elemen penting dari literasi keuangan; dan dapat dikatakan sebagai dimensi yang paling penting diantara dimensi yang lain seperi sikap dan pengtehauan keuangan. Hubungan positif antara perilaku dan literasi keuangan didorong oleh perilaku seperti perencanaan pengeluaran dan membangun jaring pengaman keuangan; sebaliknya, perilaku tertentu, seperti kredit atau pinjaman yang melampaui batas kemampuannya, dapat mengurangi kondisi dan posisi keuangan.

\section{Kesimpulan dan Saran \\ a. Kesimpulan}

Literasi keuangan (financial literacy) adalah hal penting yang seharusnya dimiliki oleh setiap pelaku usaha. Pelaku usaha UMKM dengan literasi keuangan yang baik (well literate), akan mampu melihat dimensi keuangan dengan sudut pandang yang berbeda sehingga memiliki pengetahuan untuk mengontrol kondisi keuangannya.

Rendahnya aspek literasi pelaku usaha UMKM, menjadi tantangan terhadap penyedia layanan guna menghadirkan solusi tepat guna yang mudah "dibaca". Model keagenan yang melibatkan langsung masyarakat sebagai pengganti unit perbankan akan sangat membantu proses sosialisasi dan adopsi. Institusi non-formal seperti pemain fintech juga diharapkan berpengaruh signifikan, sehingga dibutuhkan integrasi dan kerja sama anatr pelaku usaha UMKM, antar pelaku jasa keuangan akan keterjangkauan pasar produk dan pasar keuangan yang lebih menyeluruh.

UMKM di NTB dan di Kota Mataram khususnya memiliki potensi yang kuat untuk menciptakan lapangan kerja dan mengurangi kemiskinan, yakni dengan menyediakan akses ke berbagai layanan keuangan (keuangan inklusif). Sektor UMKM disiapkan agar berkembang secara cepat, serta diharapkan untuk menjangkau lebih banyak pelaku usaha di daerah perkotaan dan pedesaan.

Peningkatan literasi dan inklusi keuangan, diyakini bisa mengembangkan UMKM karena pelaku UMKM dapat lebih memahami konsep dasar dari produk keuangan, melakukan perencanaan dan pengelolaan keuangan yang lebih baik, serta melindungi mereka dari penipuan dan usaha tidak sehat di pasar keuangan.

\section{b. Saran}

Penguatan literasi dan inklusi keuangan untuk pengembangan UMKM, diperlukan sinergisitas dan optimalisasi pemanfaatan financial technology untuk memudahkan akses dan memperluas jangkauan usaha dari UMKM.

Otoritas Jasa Keuangan (OJK) dan Institusi-institusi lainnya tetap konsisten dan berkelanjutan untuk mendorong pelaku usaha UMKM guna meningkatkan akses keuangan terutama kepada industri jasa keuangan.

Saat ini, Indonesia telah memasuki dunia digital financing services. Dari segi jumlah dan volume transaksi, e-commerce dan e-banking menunjukkan tren peningkatan. Peningkatan transaksi melalui dunia digital hendaknya harus diikuti oleh pelaku usaha UMKM melalui peningkatan literasi dan inklusi dunia keuangan. 


\section{Elastisitas - Jurnal Ekonomi Pembangunan}

Vol. 2 No. 1, Maret 2020

\section{REFERENSI}

Abubakar, Habib Auwal, (2015), "Entrepreneurship Development and Financial Literacy in Africa", World Journal of Entrepreneurship, Management and Sustainable Development, Vol. 11 Iss 4 pp. 281 - 294

Akifa P. Nayla, (2014). Komplet Akuntansi untuk UMKM dan Waralaba, Laksana, Jogjakarta, hlm. 12.

Atkinson, A. and F. Messy (2012), "Measuring Financial Literacy: Results of the OECD / International Network on Financial Education (INFE) Pilot Study", OECD Working Papers on Finance, Insurance and Private Pensions, No. 15, OECD Publishing,

Paris.http://dx.doi.org/10.1787/5k9cs fs90fr4-en

BI \& LPPI. (2015). Profil Bisnis Usaha Mikro, Kecil dan Menengah (UMKM) (business profile of micro, small and medium enterprises). Jakarta: Bank Indonesia.

BPS. (2015). Profil Industri Mikro dan Kecil Tahun 2015 (Profile of micro and small enterprises). Jakarta: Badan Pusat Statistik.

BPS. (2017). Analisis Ketenagakerjaan Usaha Mikro dan Kecil (Employment analysis of micro and small enterprises). Sensus Ekonomi 2016. Jakarta: Badan Pusat Statistik.

Das, S., \& Mohiuddin, K. M. (2015). Motivational factors and the constraints of women entrepreneurship development in Bangladesh. International Journal of Information, Business and Management, 7(3), 377-396.

Fatoki, O. \& Oni, O. (2014): "Financial Literacy Studies in South Africa: Current Literature and Research Opportunities," Mediterranean
Journal of Social Sciences, Vol 5 (20), P. 409-414

Fiseha, G. G., \& Akeem, A. O. (2015). An assessment of the roles of small and medium enterprises (SMEs) in the local economic development (LED) in South Africa. Journal of Economics, 6(3), 280-290.

Grohmann, Antonia, Theres Klühs Lukas Menkhoff. (2018). Does financial literacy improve financial inclusion? Cross country evidence.World Development 111. Pp. 84-96

Ghozali, I. 2014. Structural Equation Modeling: Metode Alternatif dengan Partial Least Square (PLS).Semarang: Badan Penerbit Universitas Diponegoro Semarang.

Huston. Sandra J. (2010). Measuring Financial Literacy. The Journal of Consumer Affairs, Vol. 44, No. 2

Kebede, Matewos. (2015). Financial Literacy and Management of Personal Finance: A Review of Recent Literatures. Research Journal of Finance and Accounting www.iiste.org ISSN 2222-1697 (Paper) ISSN 2222-2847 (Online) Vol.6, No.13, 2015

Klapper,Leora Annamaria Lusardi, Peter van Oudheusden, (2015). Financial Literacy Around the World: Insights From The Standard \& Poor's Ratings Services Global Financial Literacy Survey World Bank Policy Research Working Paper

Keown, L. A. 2011. The financial knowledge of Canadians, (11).

Lusardi, Annamaria, and Olivia S. Mitchell. (2014). "The Economic Importance of Financial Literacy: Theory and Evidence." Journal of Economic Literature, 52 (1): 5-44.

Midgley, J. (2008). Microenterprise, global poverty and social development. International Social Work, 51(4), 467-479. 
Nurhidayati, Siti Eni \& Moch. Khoirul Anwar. (2018). Pengaruh Faktor Demografi Terhadap Literasi Keuangan Syariah Karyawan Perbankan Syariah Di Surabaya. Jurnal Ekonomi Islam, Volume 1 Nomor 1, Tahun 2018. Halaman 112

OECD-INFE. (2011). Measuring financial literacy: Core questionnaire in measuring financial literacy: Questionnaire and guidance notes for conducting an internationally comparable survey of financual literacy. Paris:OECD.

Olawale Fatoki (2014) The Financial Literacy of Micro Entrepreneurs in South Africa, Journal of Social Sciences, 40:2, 151-158,

Oseifuah. E. K. (2010). Financial literacy and youth entrepreneurship in South Africa. African Journal of Economic and Management Studies, Vol. 1 Iss: 2.

Orlando, María Beatriz \& Molly, Pollack (2000). Microenterprises and Poverty. Evidence from Latin America. Washington, D.C: InterAmerican Development Bank Sustainable Development Department Microenterprise Unit, February. Retrieved from

https://publications.iadb.org/bitstrea $\mathrm{m} /$ handle/11319/5035/

microenterprises $\% \quad 20$ and $\% 20$

Poverty.pdf?sequence $=1 \&$ isAllowed =y. Accessed 2 Feb 2018.

Otoritas Jasa Keuangan. (2016). Peraturan Otoritas Jasa Keuangan No 7 Tahun 2016 tentang Peningkatan Literasi dan Inklusi Keuangan di Sektor Jasa Keuangan untuk Konsumen dan/atau Masyarakat. Jakarta:OJK.

Otoritas Jasa Keuangan. 2013. Indonesia National Strategy for Financial Literacy, (Online), https://sikapiuangmu.ojk.go.id/.
Oyelana, A. A., \& Adu, E. O. (2015). Small and medium enterprises (SMEs) as a means of creating employment and poverty reduction in Fort Beaufort, eastern Cape Province of South Africa. Journal of Social Sciences, 45(1), 8-15.

Rahmana, Arief. 2008. Usaha Kecil dan Menengah (UKM), Informasi Terdepan tentang Usaha Kecil Menengah, (online), (http://infoukm. wordpress.com, diakses 1 oktober 2011)

Raghuvanshi, Juhi, Rajat, Agrawal, \& P. K. Ghosh (2017). Analysis of Barriers to Women Entrepreneurship: The DEMATEL Approach. The Journal of Entrepreneurship, 26(2), 220-238. Retrived from http://journals.sagepub.com/impactfactor/joe. Accessed 2 Feb 2018.

Robb, C. A. \& Wodyard, A. S. (2011): "Financial Knowledge and Best Practice Behaviors," Journal of Financial Counseling and Planning, Vol. 22 (1), PP.60-70

Santos, Ajoqué \& Gihan, Moustafa (2016). Female entrepreneurship in developing countries-Barriers and Motivation Case Study: Egypt and Brazil. Master of Science Thesis. KTH Industrial Engineering and Management, Stockholm. Retrieved from http://www.divaportal.se/smash/get/diva2:949759/ FULLTEXT01.pdf. Accessed 2 June 2018.

Shah, H., \& Punit, S. (2015). Women entrepreneurs in developing nations: Growth and replication strategies and their impact on poverty alleviation. Technology Innovation Management Review, 5(8), 34-43.

Tambunan, T. T. H. (2009a). Development of small and medium enterprises in ASEAN countries. New Delhi: Readworthy Publications, Ltd.. 


\section{Elastisitas - Jurnal Ekonomi Pembangunan}

Vol. 2 No. 1, Maret 2020

Tambunan, T. T. H. (2010). Trade liberalization and SMEs in ASEAN. New York: Nova Science Publishers, Inc..

Widiyati, Sri., Edi Wijayanto, Prihatiningsih. (2018). Financial
Literacy Model at Micro Small Medium Entreprise (MSMEs) MIMBAR, Vol.34 No 2 nd (December) 2018 pp. 255-264. 